Bangladesh J. Pl. Breed. Genet., 30(2): 01-08, 2017

\title{
INTER-SIMPLE SEQUENCE REPEAT ANALYSIS AND ALLELIC DIVERSITY AMONG GENOTYPES OF CULTIVATED Digitaria species
}

\author{
D. A. Animasaun ${ }^{1 *}$, K. F. Awujoola ${ }^{1}$, R. Krishnamurthy ${ }^{1,2}$ and J. A. Morakinyo ${ }^{1}$ \\ ${ }^{1}$ Department of Plant Biology, Faculty of Life Sciences, University of Ilorin, Ilorin, Kwara \\ State, Nigeria \\ ${ }^{2}$ C. G. Bhakta Institute of Biotechnology, Uka Tarsadia University, Surat, Gujarat India \\ *Correspondence author: animasaun.ad@unilorin.edu.ng
}

\begin{abstract}
Acha (Digitaria exilis Kipps. and D. iburua Stapf.) are valuable indigenous food crops in West Africa, but despite several economic potentials of this crop, little or no attention is paid to its germplasm evaluation and improvement. In this study, we assessed genetic diversity and relationship among genotypes of cultivated acha in Nigeria using Inter-Simple Sequence Repeat (ISSR) markers for the first time. Genomic DNA were extracted from the genotypes and we performed fragment amplification by Polymerase Chain Reaction (PCR). A total of 95 loci consisting of 790 bands were amplified by 13 ISSR primers, out of which $53.37 \%$ were polymorphic. Loci amplification per primer ranged from 5-10, with an average of 7.30 loci per primer. Eight of the primers had above 50\% polymorphism. Cluster analysis separated the genotypes into two major groups; a group consisting of two $D$. exilis genotypes and the other comprising a mixture of genotypes. The D. exilis in the latter group were distant members and was only similar at 0.72 similarity index. The polymorphism we obtained in the present study showed that the ISSR markers are effective for assessment of genetic diversity of the genotypes. Clustering of $D$. exilis and $D$. iburua together suggests a common progenitor but could have been separated by geographical isolation mechanism.
\end{abstract}

Keywords: Digitaria exilis; D. iburura, genetic diversity, ISSR markers, orphan crops

\section{INTRODUCTION}

Digitaria exilis (Kipps) Stapf. and D. iburua Stapf. (acha) also called fonio millets represent an integral component of millet biodiversity in the savannah zone of West-Africa. Acha belong to family Poaceae and the genus Digitaria. The genus comprises of about 230 grasses with a wide geographic distribution in the tropics and subtropics (Clayton and Renvoize, 1986). However, acha are the most economically important crops in this genus. Although, a number of wild species occurred as forage grasses, D. iburua (black acha) and D. exilis (white acha) are used for food in West and other parts of Africa (Adoukonou-Sagbadja et al., 2006).

Acha is native to West-Africa where it is cultivated in the savannah regions, but the species D. iburua is currently limited in areas of cultivation. It is only found in Northern Nigeria, Togo and Benin, which represent a relic of formerly wider cultivation (Porteres, 1946; Haq and Ogbe, 1995). Unlike D. iburua, D. exilis has wider areas of cultivation and had been reportedly cultivated in Dominican Republic (Morales-Payan et al., 2002). Acha meals are 
well appreciated for its taste and easy digestibility in many tribal areas of Guinea, Mali, Togo and Nigeria. The protein composition is rich in methionine and cystine, two vital amino-acids usually deficient in major cereals (Vietmeyer et al., 1996).

Despite the importance of this crop to traditional agriculture in West Africa, particularly Nigeria, research efforts to improve the crop is still grossly inadequate. Consequently, the crops remain primitive facing diverse agronomical problems which contributes notably to grain yield lost (Maji et al., 2003). Traditionally, local farmers distinguish three groups based on the growth cycle: precocious, intermediate and late maturing types. The first insight into the characterization of acha genetic diversity was based on morph-botanical characteristics (Porteres, 1976). However, the study did not include D. iburua due to its restricted cultivation areas. There are other reports on acha characterization using agronomic traits (Adoukonou-Sagbadja et al., 2006; Dachi and Gana, 2008).

Diversity analysis based on morphological traits may be inflated and unrealistic due to environmental influence. Since acha exhibit some level of isomorphism and difficult to distinguish morphologically during the vegetative growth stage, molecular characterization of the available germplasm is imperative. This will facilitate the use of genetic resources and estimation of genetic relatedness among the genotypes faster than the conventional methods (Semagn et al., 2006). Thus efficiency of genetic gain by selection can be improved if the patterns of genetic diversity within a population of breeding lines are known. This could be of significant importance in varietal identification, proper purity maintenance and implementation of germplasm conservation. Attempts using RAPD markers to assess the molecular variability of acha have been reported, but it involved few accessions from geographically restricted areas of Togo and Nigeria (Hilu et al., 1997).

There is still a wild gap in the knowledge of genetic diversity and molecular characterization of the West Africa acha genotypes. More also, genotypes from Nigeria were not included in the previous molecular characterization studies. Hence, the present study assessed the genetic diversity in the germplasm of two cultivated species of acha (D. exilis and D iburua) in Nigeria using microsatellite (ISSR) markers. Information on intra- and inter-specific genetic variations in the genotypes could be harnessed and utilized for breeding and improvement of the crop.

\section{MATERIALS AND METHODS}

\section{Plant Materials}

The seeds of eleven genotypes of two cultivated species of acha (D. exilis and D. iburua) were collected from different sources in Nigeria (Table 1.). The seed were grown in the net house to raise young plants for the molecular characterization. Two weeks after germination, young unfolding leaves of each genotype were harvest into separate labelled sample bottles for DNA isolation.

DNA Isolation and Polymerase Chain Reaction

Genomic DNA was isolated from $100 \mathrm{mg}$ of the leaf sample using Zymo Plant Mini Kit Zymo Research, USA). The quality of the DNA was checked on $0.8 \%$ agarose gels and the DNA concentrations estimated using a Nanodrop 8000 spectrophotometer (Nanodrop 
Technologies, USA). A total of 21 Inter-Simple Sequence Repeat (ISSR) primers were initially used for the Polymerase Chain Reaction (PCR). The final reaction volume was $20 \mu 1$ in in thin wall PCR tube (Axygen; USA). Each reaction mixture consisted of $1.0 \mu \mathrm{l}(50 \mathrm{ng})$ of gDNA, $1.0 \mu \mathrm{l}$ of primer $(10 \mathrm{pmol} / \mathrm{ml}), 10.5 \mu \mathrm{l}$ of $1 \mathrm{X}$ PCR mix $(3 \mathrm{mM} \mathrm{MgCl}, 0.2 \mathrm{mM}$ dNTPs, one unit of Taq DNA Polymerase (Fermentas, Life Sciences) and $7.5 \mu 1$ nuclease free water. The PCR was performed on Thermal cycler (Applied Biosystems, USA). The PCR conditions include the initial denaturation at $94{ }^{\circ} \mathrm{C}$ for 2 minutes followed by 40 cycles of final denaturation at $94{ }^{\circ} \mathrm{C}$ for 30 seconds, primer annealing at $27{ }^{\circ} \mathrm{C}$ (varied based on primer Tm) for 45 seconds and extension at $72{ }^{\circ} \mathrm{C}$ for 90 seconds. Final extension was at 72 ${ }^{\circ} \mathrm{C}$ for 10 minutes and the system was put on hold for at $4^{\circ} \mathrm{C}$ for 10 minutes. $5 \mu \mathrm{l}$ of the PCR products was mixed with $1 \mu \mathrm{l}$ of $6 \mathrm{X}$ gel loading dye and electrophoresed on $1.5 \%$ agarose gel stained with ethidium bromide using $1 \mathrm{X}$ TAE buffer. Fragment sizes of the amplified products were anticipated from the gel by comparison with standard molecular weight marker (Thermofisher, USA). The amplified product was visualized as a single compact band under UV light and documented by gel documentation system (SIGMA-3-16KL).

\section{Data Analysis}

Reproducible and clear bands were score as 1 for presence and 0 for absence across the lanes in reference to the standard marker. The data were subsequently used to construct a dendrogram using the unweighted pair group method of arithmetic averages (UPGMA). All the computations were carried out using the NTSYpc (Numerical Taxonomy and Multivariate Analysis System) software version 2.

\section{RESULTS AND DISCUSSION}

The concentrations of genomic DNA extracted from the genotypes of acha ranged from 123.81-186.03 g/ $\mu$ l, the OD (Optical Density) at 260/280 $\mathrm{nm}$ was between 1.51 and 1.72 (Table 2). Amplification of DNA fragment by PCR depends on quality of the gDNA among other factors. The quality is usually measured by Optical Density (OD) of Absorbance reading at $260 \mathrm{~nm}$ and $280 \mathrm{~nm}$. A good DNA has ratio of $\mathrm{OD}_{260} / \mathrm{OD}_{280}$ between 1.8 and 2.0, values below and above this range signify protein and RNA contaminations respectively. Highest DNA concentration of $186.03 \mathrm{~g} / \mu 1$ was found in a D. iburua, Nopiya and the least $(123.81 \mathrm{~g} / \mu \mathrm{l})$ recorded in another genotype Gwabi. Similarly, genotypes Gopanto and Ndai which are both D. iburua had the highest (O.D 1.72) and least (O.D 1.51) purity respectively. The OD values obtained in this study produced good amplification. This is due to the ability of the PCR technique to amplify DNA with relatively small impurity. To corroborate this, Scotti et al. (1999) remarked that DNA with low OD values could give a good PCR product, however, this statement is relative and did not distinctively elucidate the degree of impurity the technique could accommodate. In addition, DNA with OD values less than 1.5 was successfully amplified for SSR genetic analysis (Otoo et al., 2009).

Out of the twenty ISSR primers tested, thirteen ISSR markers produced remarkable and reproducible fragments. The number of amplified loci, monomorphic and polymorphic bands as well as the percentage polymorphism expressed by each of the primers is presented in Table 3. A total of 95 bands were generated by 13 primers with average of 7.30 loci per primer. Inter and intra- specific diversity assessment of germplasm is useful in conservation of genetic resources and prediction of combining ability of breeding materials. Fragment 
amplification by the ISSR primers revealed inter and intra-genetic diversity among the genotypes of $D$. exilis and $D$. iburua in Nigeria. The genotypes showed considerable heterologous amplification of the alleles where about $46 \%$ were monomorphic and over $53 \%$ were polymorphic, this indicated that the ISSR markers are effective in revealing genetic variations in the genotypes. This is in agreement with earlier workers who had demonstrated that microsatellite markers are effective in genotyping and fingerprinting of plant accessions (Ajibade et al., 2000; Animasaun et al., 2015).

Table 1. Genotype name, common name, and source of $D$. exilis and D. iburua used for the study

\begin{tabular}{lccc}
\hline Genotype & Name & Common name & Source $^{\dagger}$ \\
\hline Gwabi & D. iburua & Black acha & NCRI \\
Kereep & D. exilis & White acha & NCRI \\
Agyong & D. exilis & White acha & NCRI \\
Gopanto & D. iburua & Black acha & NCRI \\
Ndai & D. exilis & White acha & NCRI \\
Nopiya & D. iburua & Black acha & NCRI \\
Bauchi & D. iburua & Black acha & Field \\
NGB00629 & D. exilis & White acha & NACGRAB \\
Niger & D. iburua & Black acha & Market \\
Kebbi & D. exilis & Black acha & Field \\
Kebbi-2 & D. iburua & Black acha & Field \\
\hline
\end{tabular}

NCRI: National Cereal Research Institute, Badeggi Niger state Nigeria

'NACGRAB: National Centre for Genetic Resources and Biotechnology, Ibadan, Nigeria

Table 2. Concentrations and purity of gDNA extracted from eleven genotypes of Digitaria exilis and $D$. iburua, the two common varieties grown in Nigeria

\begin{tabular}{llll}
\hline S/No & Genotype & gDNA g/ $\mu \mathrm{l}$ & ${ }^{\dagger}$ OD 260/280 nm \\
\hline 1 & Gwabi & 123.81 & 1.54 \\
2 & Kereep & 164.23 & 1.68 \\
3 & Agyong & 176.14 & 1.71 \\
4 & Gopanto & 178.40 & 1.72 \\
5 & Ndai & 158.21 & 1.51 \\
6 & Nopiya & 186.03 & 1.71 \\
7 & NGB00629 & 176.14 & 1.62 \\
8 & Bauchi & 167.04 & 1.58 \\
9 & Niger & 158.42 & 1.51 \\
10 & Kebbi-1 & 169.61 & 1.58 \\
11 & Kebbi-2 & 160.11 & 1.54 \\
\hline
\end{tabular}

A high number of alleles and polymorphism are important for correct estimation of genetic diversity of a germplasm. Figure 1 showed the frequency of amplification by each of the primer. Primers ISSR5 and ISSR 10 had highest allelic frequency of 79 and 70 respectively 
followed by ISSR 13 which occurred in nine loci but marked by 70 alleles. ISSR 8 had the least allelic frequency but interestingly had the highest polymorphism.

Table 3. Amplification and polymorphism pattern of ISSSR markers used in the diversity study of accessions of Digitaria $\mathrm{spp}$

\begin{tabular}{llllllll}
\hline SN & $\begin{array}{l}\text { Marker } \\
\text { code }\end{array}$ & \multicolumn{1}{c}{ Sequence (5 - 3 ) } & TNA & TNL & $\begin{array}{l}\text { NM } \\
\text { L }\end{array}$ & NPL & P(\%) \\
\hline 1 & ISSR1 & GAGAGAGAGAGACC & 51 & 6 & 3 & 3 & 50.00 \\
2 & ISSR2 & CTCTCTCTCTCTCTCTAC & 64 & 6 & 2 & 4 & 66.67 \\
3 & ISSR3 & CACACACACACAAG & 62 & 7 & 4 & 3 & 42.90 \\
4 & ISSR4 & CAGCACACACACACACA & 66 & 6 & 4 & 2 & 33.33 \\
5 & ISSR5 & GTGTGTGTGTGTCC & 79 & 10 & 4 & 6 & 60.00 \\
6 & ISSR6 & CTCTCTCTCTCTCTCTGC & 67 & 7 & 3 & 4 & 57.14 \\
7 & ISSR7 & GAGAGAGAGAGAGG & 73 & 8 & 4 & 4 & 50.00 \\
8 & ISSR8 & AGCACGAGCAGCAGCGG & 35 & 7 & 2 & 5 & 85.71 \\
9 & ISSR9 & CACACACACACACAAT & 67 & 8 & 5 & 3 & 37.50 \\
10 & ISSR10 & AGCACGAGCAGCAGCGT & 70 & 10 & 3 & 7 & 70.00 \\
11 & ISSR11 & GTGTGTGTGTGTGTTG & 43 & 5 & 3 & 2 & 40.60 \\
12 & ISSR12 & GTGTGTGTGTGTGTCT & 43 & 6 & 4 & 2 & 33.30 \\
13 & ISSR13 & GCTGAGAGAGAGAGAGA & 70 & 9 & 6 & 3 & 66.67 \\
\hline
\end{tabular}

TNA $=$ Total number of allele; TNL $=$ Total number of loci, NML $=$ Number of monomorphic loci, NPL $=$ Number of polymorphic loci, $\% \mathrm{P}=$ Percentage polymorphism

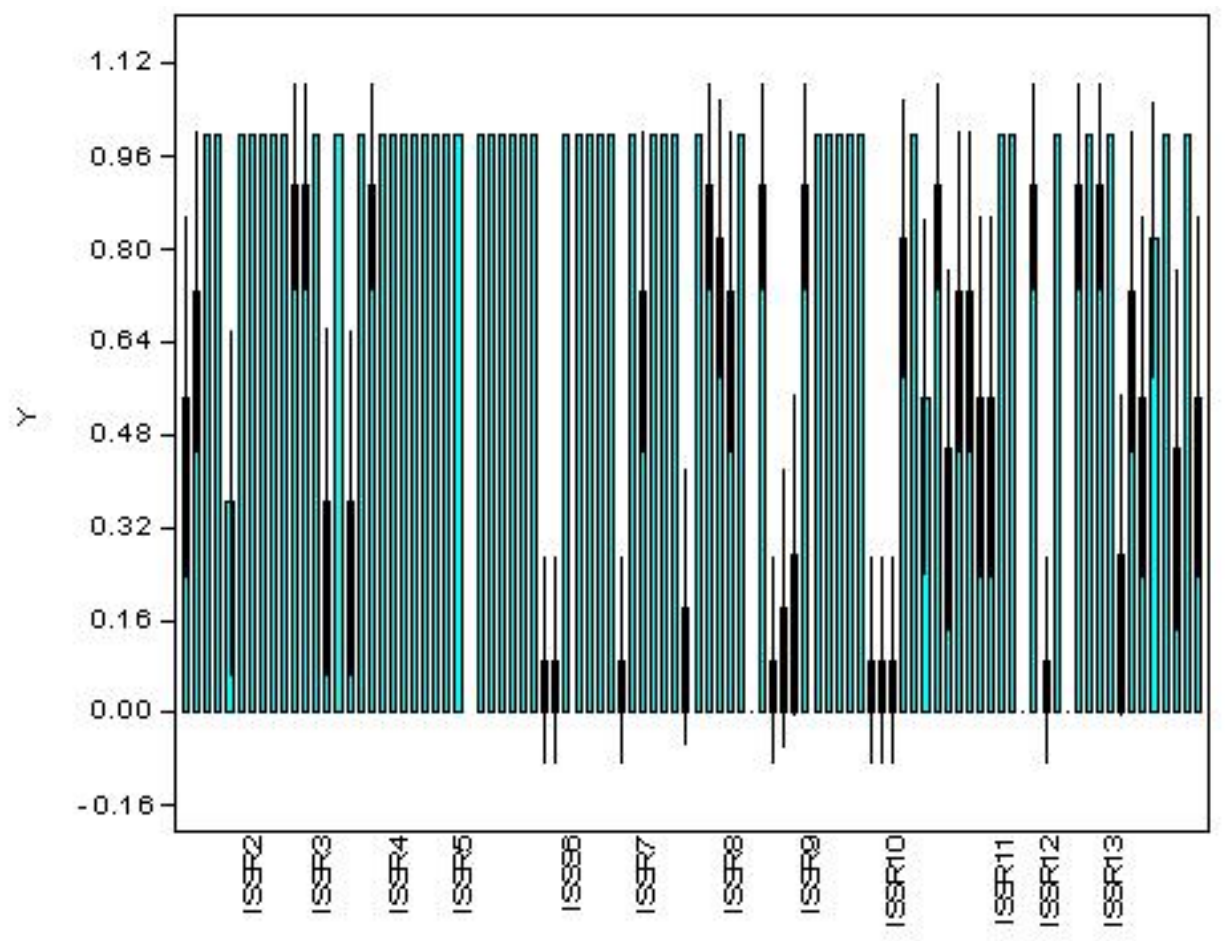

Fig 1. Allelic frequency amplification of the thirteen ISSR primers on eleven Nigerian acha genotypes (key: Y-axis: the allelic frequency; X-axis: the ISSR markers used for the diversity study). 
The frequency of null allele was highest in primer ISSR11. Since, microsatellite profile are commonly interpreted in terms of allele phenotype, the degree of polymorphism correlates to diversity and effectiveness of the markers (Pfeiffer et al., 2011). Although a few of the markers had low allelic frequencies and percentage polymorphism, most of the primer produced higher polymorphism. Significantly low numbers of alleles and gene diversity was recorded in cultivated pearl millet accessions compared with wild accessions using SSR markers (Oumar et al., 2008). However, Azevedo et al., (2012) reported high loci amplification and polymorphism in napier grass and millet accessions using microsatellite markers.

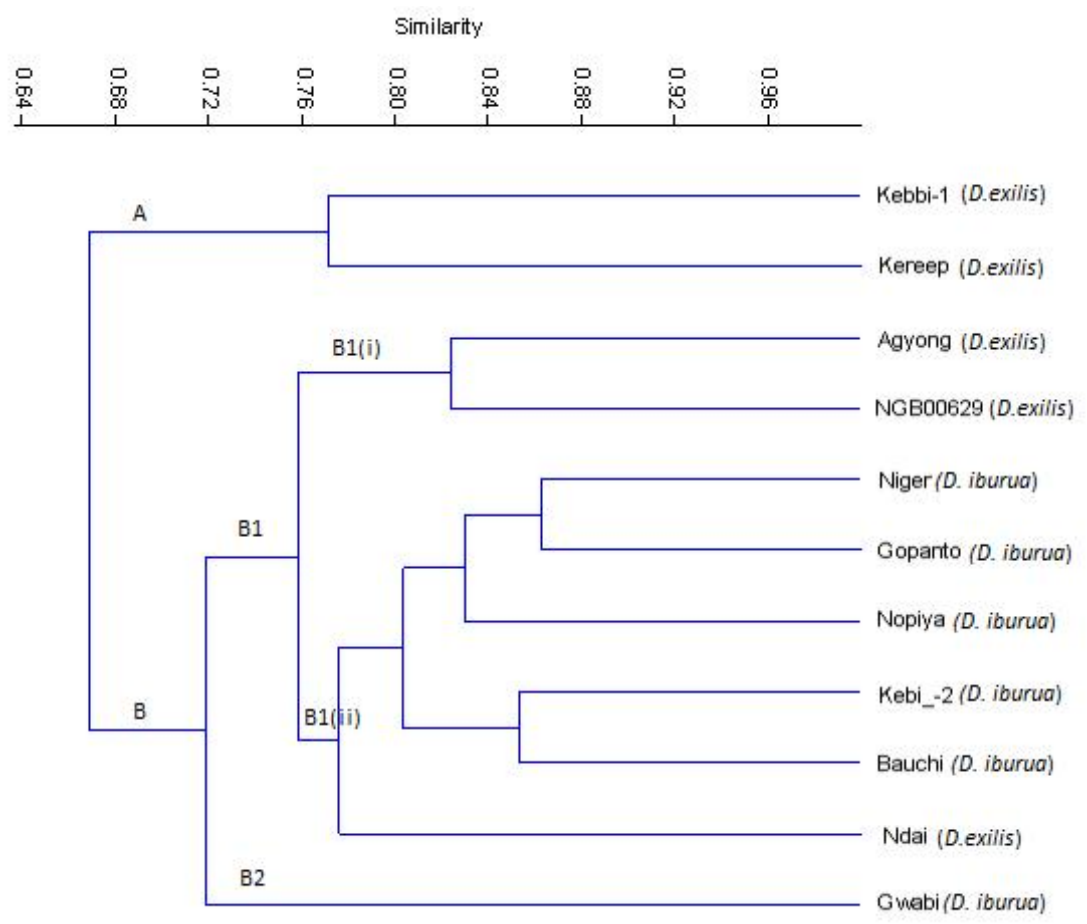

Fig 2. Dendrogram showing genetic relationship among the genotypes of white $(D$. exilis) and black (D. iburua) acha cultivated in Nigeria.

The genetic similarity among the eleven genotypes of acha (fonio millet) revealed average relationship. At similarity index of 0.68 , the dendrogram as defined by the thirteen ISSR markers revealed two major groups; A and B (Fig 3). Group A consisted of two D. exilis (white acha) genotypes; Kebbi-1 and Kereep which are similar at 0.78 index. The second group (group B) had two subgroups (B1 and B2). The B1 had two clusters, whereas cluster B1(i) had two D. exilis members that are $84 \%$ similar, B1(ii) comprised of six genotypes of five $D$. iburua and a $D$. exilis, with the latter separated from the other five D. iburua members at 0.80 index scale. The genetic relationship that exits between Agyong, NGB00629, Ndai which are all exilis genotypes but clustered with the iburua suggested they are genetically linked. 
The other five members are more similar, but the closest genotypes of this cluster are Kebbi2 and Bauchi. In contrast to the B1 sub-group, the B2 had only one genotype, Gwabi $(D$. iburua) a black fonio millet which is distantly separated from the other D. iburua genotypes in group B. The result of cluster analysis revealed that basically, D. exilis are genetically dissimilar from the D. iburua, nevertheless, some degree of intra-specific diversity also existed. The genetic variation in these two species was earlier reported (Hilu et al., 1997; Adoukonou-Sagbadja et al., 2006). Although their summations were based on morphological and agronomical studies, the pattern of cluster obtained in this study was similar to their reports and congruent to Hilu (1995). This suggests a common progenitor for the species.

\section{CONCLUSION}

Accurate assessment of genetic diversity is important in crop breeding and adequate genetic information would identify potential parental combinations to create segregating progenies with maximum genetic variability for further selection. Findings from the present study showed that ISSR markers are valuable asset for estimating genetic diversity. The polymorphism obtained indicated remarkable inter and intra-specific variation among the available genotypes of acha in Nigeria. Occurrence of $D$. exilis and $D$. iburua together in a cluster revealed their relatedness and suggesting a common ancestor. It is however imperative that more genotypes and wild relatives from diverse sources be evaluated for diversity and phylogeny to provide broader gene pool from where selection can be made for a breeding program to improve the crop

\section{REFERENCES}

Adoukonou-Sagbadja, A. H. 2010. Genetic Characterization of traditional fonio millets (Digitaria exilis, D. iburua Stapf.) Landraces from West-Africa: Implications for conservation and breeding. Ph.D. thesis, Justus-Liebig University, Giessen, Germany. p.107.

Adoukonou-Sagbadja, H., A. Dansi, R. Vodouhè and K. Akpagana. 2006. Indigenous knowledge and traditional conservation of fonio millet (Digitaria exilis Stapf, Digitaria iburua Stapf) in Togo. Biodivers Conser. 15:23-29.

Ajibade, S. R., N. F. Weeden and S. Michite 2000. Inter simple sequence repeat analysis of genetic relationships in the genus Vigna. Eupytical, 111: 47-55

Animasaun, D. A., J. A. Morakinyo, O. T. Mustapha and R. Krishnamurthy. 2015. Assessment of genetic diversity in accessions of pearl millet (Pennisetum glaucum) and napier grass (Pennisetum purpureum) using micro satellite (ISSR) markers. Iranian J. Genet. Plant Breed. 4(1): 25-35.

Azevedo, A. L., P. P. Costa, J. C. Machado, M. A. Machado, A. V. Pereira and F. J. da Silava Ledo. 2012. Cross species amplification of Pennisetum glaucum Microsatellite markers in Pennisetum purpureum and genetic diversity of Napier grass accessions. Crop Science. 52: 1776-1785.

Clayton W. D. and S. A. Renvoize. 1980. Genera Graminum, grasses of the world. Kew Bull Add Series XIII.

Dachi, S. N. and A. S. Gana. 2008. Adaptability and yield evaluation of some Acha (Digitaria exilis and Digitaria iburua Kippis Stapf) accessions at Kusogi - Bida, Niger State, Nigeria. African Journal of General Agriculture. 4(2): 73-77. 
Haq, N. and F. D. Ogbe. 1995. Fonio (Digitaria exilis and Digitaria iburua): Cereals and pseudocereals, boundary row, Chapman \& Hall, London. p 2-6.

Hilu, K. W. 1995. Evolution of finger millet: evidence from random amplified polymorphic DNA. Genome. 38: 232-238.

Hilu, K. W.; K. M'Ribu, H. Liang and C. Mandelbaum. 1997. Fonio millets: ethnobotany, genetic diversity and evolution. S Afr. J. Bot. 63: 185-190.

Maji, A. T.; S. N. Dachi and J. Yisa. 2003. Evaluation of Morphological variations within and between 10 Acha collections in NCRI accessions. NCRI Annual Report. 90-94.

Morales-Payan, J. P., J. R. Ortiz, J. Cicero and F. Taveras. 2002. Digitaria exilis as a crop in the Dominican Republic. In J. Janick and A. Whipkey (eds.). Supplement to Trends in new crops and new uses. ASHS Press, Alexandria, VA; p. S1-S3.

Otoo, E., R. Akromah, M. Kolesnikova-Allen and R. Asiedu. 2009. Delineation of pona complex of yam in Ghana using SSR markers. International Journal of Genet. Mol. Biolo. 1(1): 006-016

Oumar, I., C. Mariac, J. L Pham and Y. Vigouroux 2008. Phylogeny and origin of pearl millet (Pennisetum glaucum [L.] R. Br) as revealed by microsatellite loci. Theor. Appl. Genet. 117: 489-497

Pfeiffer, T., A. M. Roschanski, G. PannellKorbecka and M. Schnitter 2011. Characterization of microsatellite loci and reliable genotyping in a polyploidy plant, Mercurialis perennis (Euphorbiaceae). J. Heredi. 102: 479-488.

Portères, R. 1946. L'aire culturale du Digitaria iburua Stapf, céréale mineure de l'ouestAfricain. Agron Trop. 1: 589-592

Portères, R. 1976. African Cereals: Eleucine, Fonio, Black Fonio, Teff, Brachiaria, Paspalum, Pennisetum and African Rice. In J. R. Harlan, J. M. J. de Wet and A. B. L. Stemler, (eds.). Origin of African plant domestication. Mouton Publishers, The Hague, p. 409-451

Semagn, K., A. Bjørnstad and M. N. Ndjiondjop. 2006. An overview of molecular marker methods for plants. Afr J. Biotechnol. 5: 2540-2568.

Scotti, I., G. Paglia, F. Magni and M. Morgante. 1999. Microsatellite markers as a tool for detection of intra- and interpopulational genetic structure. In E. D. Gillet (ed.) Which DNA marker for which purpose? Final Compendium of the Research Project Development, Oprtimization and validation of molecular tools for assessment of biodiversity in forest trees in the European Union DGXII Biotechnology. FW IV Research Programme Molecular Tools for Biodiversity. http://webdoc.sub.gwdg.de/ebook/1999/whichmarker/index.htm

Vietmeyer, N. D.; N. E. Borlaugh, J. Axtell, G. W. Burton, J. R. Harlan and K. O. Rachie. 1996. Fonio (Acha) Lost crop in Africa. BOSTID Publication. p. 59-7. 